\title{
Introduction: New Directions in Political History
}

\author{
James Epstein
}

Announcing the resurgence of "the political" is unlikely to surprise readers of this journal. Over the past two decades, political history has staged a remarkable comeback, one that has been colored by the "linguistic" and "cultural" turns in the humanities and social sciences. Less concerned with the formal processes of government and institutions of the state, the new political history has turned more often to the symbolic investments of actions and communication, to questions about how meanings are produced, received, and sustained. The politics of meaning and the meaning of politics are intertwined. This shift in orientation is paralleled in literary studies, where new historicists have recast discussions of "art" into discussions of "representations," broadening the range of literary studies to larger cultural matrices. ${ }^{1}$ To the extent that institutions of the state remain primary objects of study, Michel Foucault's work has proved crucial, mapping the dispersal of authority across a range of sites. This is not the place to attempt a full genealogy of this political turn, although it is fair to say that its origins lay in the work of French historians and their dissatisfaction with prevailing social interpretations of the French Revolution. François Furet's expressed dissatisfaction with marxist orthodoxy and his insistence on restoring the Revolution's "most obvious [political] dimension" were particularly influential. ${ }^{2}$ Politics viewed as a field irreducible to social determinants is among the cardinal principles of the new history of political culture, although questions about how to reformulate the relationship between cultural representations and social structures remain open.

The articles brought together in this issue reflect some of these

${ }^{1}$ See, most recently, Catherine Gallagher and Stephen Greenblatt, introduction to Practicing New Historicism (Chicago, 2000).

${ }^{2}$ François Furet, Interpreting the French Revolution, trans. Elborg Forster (Cambridge, 1981), p. 27. Also see the comments of Colin Jones and Dror Wahrman, "Introduction: An Age of Cultural Revolutions?" in The Age of Cultural Revolutions, Britain and France, 1750-1820, ed. Colin Jones and Dror Wahrman (Berkeley, 2002), particularly pp. 11-12. The work of Lynn Hunt was especially important in brokering this shift for Anglo-American scholars, particularly her Politics, Culture, and Class in the French Revolution (Berkeley, 1984). 
new directions. Unlike most special issues, however, this one developed spontaneously, in itself a measure of the richness and vitality of political history. In her article, "The Quest for a King: Gender, Marriage, and Succession in Elizabethan England," Anne McLaren revisits the muchdebated subject of monarchical marriage strategies during Elizabeth I's reign. She explores the linkages among gender, marriage, and kingship "as contemporaries understood them," requiring an appreciation of the increasingly tight relationship between marriage and "kingly identity" brought on by the Protestant Reformation. Throughout Europe, the Reformation was associated with a drive to "enthrone godly kings and disallow female rule" (p. 263). McLaren's reinterpretation of the politics of succession turns on the imperative of male godly rule and, ultimately, a shifting away from "belief in kingship as embodied essence to its abstract conceptualization as an office of state" (p. 265). Her article illustrates the more general claim that contemporary understandings of gender order are imbricated within the very texture of historical experience, central to the production of political, social, and religious authority.

"They act like the comedians of a fair before a riotous audience; they act amidst the tumultuous crises of a mixed mob of ferocious men, and of women lost to shame ... [who] sometimes mix and take their seats amongst them."3 For Edmund Burke, the low theatricality and mixing of sexes at the French National Assembly signal the disorder of its proceedings and the inversion of authority produced by the Revolution. As Kevin Gilmartin recognizes in his article, "In the Theater of Counterrevolution," the age of revolutions witnessed a crisis in representation that absorbed the minds of both conservatives and reformers. It was not only Burke who drew connections between theater and social order. Gilmartin offers a sustained reading of William Paley's Reasons for Contentment (1793), which opens by comparing social order to the experience of the theater. The unresolved ambiguities in Paley's summoning of the social world of the theater and reasoning common readers into contentment are indicative of a more general condition. Gilmartin argues that the burden of the figure of the theater in Paley's work, in which attention is shifted away from the stage to the social relations of the audience, not only underscores the appeal for conservatives of a society "that holds its ordinary subjects just below the threshold of political consciousness" (p. 311), but it demonstrates the futility of imagining a prepolitically conscious society in the wake of the French Revolution. Thus arises the needs to direct and organize plebeian sentiment, to ad-

${ }^{3}$ Edmund Burke, Reflections on the Revolution in France: A Critical Edition, ed. J. C. D. Clark (Stanford, Calif., 2001), p. 229. 
dress the poor and manage the terms of address, and to constitute a counterassociation while subordinating loyalism to government supervision. Gilmartin shows how the difficulties present within Paley's work are reproduced more generally within the loyalist association movement and throughout the "archive of antirevolutionary association" (p. 318), the works published under the auspices of the movement associated with John Reeves. The methods of new historicist literary criticism, close textual readings, and political history are brought together here to superb overall effect.

The theaters of war and revolution gave new urgency to the issue of commemoration and remembrance. On his return to England from America, to the derision of conservatives, William Cobbett brought "home" the bones of Thomas Paine, as the proper site of national memory. Across the channel, the question of how to memorialize and remember the Revolution's agony and glory assumed life-and-death urgency. The corpse of Marat was laid out at the Cordeliers, was paraded during the funeral ceremony during which "the people of Paris communed one last time with their 'friend,', and was painted by Jacques-Louis David. ${ }^{4}$ New sites/sights of memory, appropriate to the education of the republican citizen, had to be invented.

Pierre Nora has developed the concept of "places of memory" (lieux de mémoire), modern sites of national memory that he contrasts to "environments of memory" (mileux de mémoire), the embedded, lived habits and traditions of communal memory. ${ }^{5}$ Alas, Paine's bones never became such a site of memory since their burial place remains unknown. Not so the remains of Roger Casement. In his article, "Bones of Contention," Kevin Grant examines the fifty-year conflict over repatriating Casement's remains. In the case of Casement, who was executed by the British in 1916 for treason, the politics of the body and the national body politic came together in complex fashion. In order to discredit the Irish nationalist hero, the British government leaked details of the socalled "Black Diaries," purported to have been written in Casement's hand and containing detailed descriptions of homosexual encounters. Grant emphasizes the ambivalence with which Irish republican leaders, particularly Eamon de Valera, viewed and represented Casement as a national symbol. In addition to the controversy over his sexual orientation, Casement's allegiances across Ireland's politico-sectarian divide also troubled the Irish government. Grant concludes that the burial of

${ }^{4}$ Antoine de Baecque, Glory and Terror: Seven Deaths under the French Revolution, trans. Charlotte Mandell (New York, 2001), p. 7.

5Pierre Nora, "Between Memory and History: Les Lieux de Mémoire," Representations 26 (Spring 1989): 7-25. 
Casement in 1965 in the Republic of Ireland rather than, as he had requested, near his family home in Ulster symbolized the Republic's submission to partition, standing as an ironic place of memory and forgetting, "an Irish national monument to national disunification"' (p. 330).

Whereas the politics of memory and identity constitute a major new direction for political history, historians have been more reluctant to link histories of emotional culture to the world of politics. ${ }^{6}$ Martin Francis, in his article "Tears, Tantrums, and Bared Teeth," considers the "emotional economy" of politics in the postwar period, investigating how the "dominant codes of masculine emotional culture" operated within high politics (p. 355). More particularly, he aims to recover the emotional conventions governing Conservative political culture as they pertained specifically to the careers of Winston Churchill, Anthony Eden, and Harold Macmillan. Martin focuses on a crucial aspect of "the linkages between private feeling and the changing styles of personal deportment in the realm of high politics," what he terms the "culture of 'restraint", (p. 357). Eden's inability to control his emotions gave way to Macmillan's presence of restraint, although in some ways this restored calm moved against a more widely perceived shift in social values toward a culture of self expression.

This special issue concludes with a wide-ranging essay by Annabel Patterson, who surveys the new literature on print culture in the early modern period. She identifies a major paradigm shift, possessing a number of components, including the chronological expansion of the term "early modern" to the sixteenth century, the loosening of the boundaries between academic disciplines, and the fact that a familiarity with the concept of the public sphere and the work of Jürgen Habermas is now taken for granted. Most significantly, however, is the "absorption of a whole new body of work . . . not on motives or special interest groups or resistance movements or women, but on books" (p. 389). And as she approvingly notes, the emphasis is on books not "texts," "books and their makers, books and their readers"' (p. 389). Patterson proceeds to take us on a critical tour de force of the some of the most recent and innovative works about books, readers, and the political consequences of these cultural currents.

${ }^{6}$ For what is at stake more generally, see William M. Reddy, "Against Constructionism: The Historical Ethnography of Emotions," Current Anthropology 18, no. 3 (1997): $327-51$. 